\title{
Formation of Muslim Identity in the Millennial Era (An Analysis of Ibn 'Athaillah al-Iskandari's al-Hikam)
}

\author{
A Syahriar ${ }^{1}$ \\ Universitas Islam Nahdlatul Ulama Jepara, Indonesia $^{1}$ \\ \{alfasyahriar@unisnu.ac.id ${ }^{1}$ \}
}

\begin{abstract}
This paper aims to examine the thoughts of Ibn 'At $\} a>$ Alla $>h$ alIskandari $>$ in his book of al-Hikam on the formulation of Muslim identity in the millennial era. Muslims have been currently considered facing the problem of identity crisis resulted in the decline of Islamic civilization and the noncompetitiveness in various fields of life despite the historical fact that it had played an important role in changing the course of world civilization. The paper argues that the Muslim identity determines the course and purpose of life with all its dynamics as Muslims are obliged to take a role in life. This research is qualitative in which it seeks to examine the thoughts of Ibn 'At $\} a>$ Alla $>$ h alIskandari on the formulation of Muslim identity. This study is based on the author's critical accounts of his al-Hikam as the primary source and its explanatory (syarh) as the secondary source. The data was collected through a documentation technique, which was then analyzed using a hermeneutic approach. This study found that Ibn 'At $\} a>$ Alla $>$ h al-Iskandari divided the formation of Muslim identity into three categories: (1) rabbaniyya, (2) insaniyya, and (3) akhlaqiyya, all of which show a unique and independent feature of Muslim identity having its relevance with the Millennial era.
\end{abstract}

Keyword: Muslim identity, Millennial era, Ibn ‘At $\} a>$ Alla $>$ h al-Iskandari

\section{Introduction}

The word millennial is derived from the English millennium or millennia, which means 'a thousand years'. The millennial era is a period of a thousand years or more. The term is used to refer to a period taking place after the modern era and, therefore, it is often called the postmodern era [1]. The modern era is characterized by its achievements based on the use of reason and material-oriented considerations. On the other hand, the aspects of values, including morals and religion, are ignored so that human beings have full freedom to do something without adherence to the principle of free values. Modernity is undeniable and it helps human beings obtain amazing achievements in all aspects of life, especially in technology. However, all these achievements are nothing more than just lust when moral values are out of consideration.

The paradigm of life that prevails in the modern era can be said to be rather artificial because the basic assumption is that all problems of life will be solved just by the reason and 
the senses in which technological sophistication is seen as the main savior. However, we can be sure that the assumption is far from the truth because the existing problems are very complex with significant and sustainable impacts for which the limited human mind and senses are difficult to understand.

Therefore, some experts see the presence of the millennial as an era that provides a balance of achievements in the modern era. It is due to the assumption that the millennial era is an era of going back to spirituality and morality or to religion in which human beings will return to the spiritual, moral and religious.

In relation to human characteristics in the current millennial era, there are at least 14 characteristics formulated by experts, as quoted by Abuddin Nata [1]. They include (1) love of freedom; (2) love of self; (3) reliance on instant information; (4) love for learning; (5) working within innovative environments; (6) eagerness to collaborate; (7) hyper-technology; (8) thinking out of the box, rich ideas; (9) self-confidence; (10) good at socializing; (11) surfing on social media and the internet; (12) high dependence on the internet so they are lazy, not down to earth and dissocializing; (13) weak sense of togetherness, mutual cooperation, environmental warmth, and social care; (14) tend to be free, westernized, do not pay attention to formal ethics and rules, customs and manners.

At this time, the millennial era is underway. There seems to be an unfavorable and paradoxical situation because in reality the millennial era cannot be separated from the shadows of the modern era. The situation is severe. There is homework that has not yet been completed. Many problems that have arisen in modern times have not yet been solved, while in the millennial there era many problems whose core has not been yet identified and resolved.

In line with it, on the side of human resources, it should be noted that these 14 characteristics are considered unique identities for the millennial generation. Meanwhile, the reality in the context of Indonesia is experiencing a demographic bonus, where the percentage of the population in the productive age is very high, being incidentally dominated by the younger generation, and the majority is Muslims. This condition, in essence, emphasizes that the identity of the young Muslim generation is being faced with challenges and obstacles in the dynamics of life in the millennial era.

The perspective of Ibn 'At $\} \mathrm{a}>$ Alla $>\mathrm{h}$ al-Iskandari in seeing the problem would find the right momentum to unravel the red line of Muslim identity in this millennial era. His perspective of Sufism will be able to provide a clear inspiration on how Muslims, especially the younger generation, should address this millennial era proportionally. Abu al-Wafa $>$ alGhani $>$ mi al-Tafta $>$ zaniy [2] explains that the full name Ibn 'At $\} a>$ Alla $>\mathrm{h}$ al-Iskandari is Ahmad Ibn Muhammad Ibn Abdul Kari $>$ m Ibn Abd al-Rahman Ibn Abdullah Ibn Ahmad Ibn Isa Ibn al-Husain Ibn 'At $\} a>$ Alla $>h$. He has the nickname Ta $>$ j al-Di $>n, A b u>$ al-Fadhl and $\mathrm{Abu}>\mathrm{al}-\mathrm{Abba}>\mathrm{s}$. It was stated that he was a resident of Alexandria, so that the usual names were added al-Iskandara $>$ niy.

Ibn 'At $\} a>$ Alla $>$ h al-Iskandari was born in the city of Alexandria. As for the year of his birth, there is no definitive year, but he was dead in 709 AH in Cairo, Egypt. Al-Rundi [3] divides the life journey of Ibn 'At $\} a>$ Alla $>$ h al-Iskandari into three phases. The first phase is the span of time before $674 \mathrm{H}$ in the city of Alexandria, where Ibn 'At $\} a>$ Alla $>$ h al-Iskandari is studying scientific knowledge to some experts about Tafsir, Hadith, Fiqh, Usul Fiqh, Arabic Grammar and other disciplines. The second phase is in the span of time after $674 \mathrm{H}$, during which Ibn 'At $\} a>$ Alla $>$ h al-Iskandari became acquainted with Abu al-Abbas al-Mursy. This phase was ended by the transfer of Ibn 'At $\} a>$ Alla $>h$ al-Iskandari to Cairo, Egypt, to pursue the world of the al-Syadzali tariqah and keep seeing religious knowledge. 
The third phase was marked by the migration of Ibn 'At $\} a>$ Alla $>h$ al-Iskandari from Alexandria to Cairo where he settled for a long time until his death in Jumadal Akhirah 709 Hijria at Madrasah al-Manshuriyah, Cairo, Egypt. $\mathrm{He}$ was buried in Qarrafah [4].

The book of al-Hikam is referred to as Ibn 'At $\} a>$ Alla $>\mathrm{h}$ al-Iskandari's writing. The book is phenomenal for Muslims for it has been extensively discussed in religious forums and has been studied by Muslim scholars resulted in a number of explanatory writings. Al-Hikam is written in a style that is easily digested while the content and the scope is very deep and comprehensive [4].

Al-Hikam was compiled by Ibn 'At $\}$ a $>$ Alla $>$ h al-Iskandari. It consists of 264 words of wisdom all of which are based on four important pillars, including: (1) Insights on dhikr and advice. (2) Purification of activities and improvement of conditions. (3) The manifestation of the conditions and position of God's servant. (4) Scientific insights and divinity. The book is ended with the arrangement of Munajat to Allah [4].

Based on the above description, this research aims to examine more deeply the thoughts of Ibn 'At $\} a>$ Alla $>$ h al-Iskandari as explicitly conveyed in his book al-Hikam in regard to the Muslim identity in the millennial era. The purpose is that every Muslim will have a unique identity and an independent personality in this life.

\section{Method}

This research is conducted using a descriptive qualitative approach. That is, the author will interpret the statements of Ibn 'At $\} \mathrm{a}>$ Alla $>$ h al-Iskandari that contain a variety of meanings and a large of wisdom as summarized in his book of al-Hikam along with the surrounding context. The author will then explain systematically and accurately the facts and characteristics of the data drawn from the interpretation [5].

The study uses a library research method, in which the author performs a critical analysis of some of Ibn 'At $\} \mathrm{a}>$ Alla $>\mathrm{h}$ al-Iskandari's wisdom statements in his book of al-Hikam according to library materials [6].

Variants of data related to research focus are collected through documentation techniques. The author takes Ibn 'At $\} \mathrm{a}>$ Alla $>$ h al-Iskandari's thoughts in his book of al-Hikam as the primary source and the explanatory books (sharh) as the secondary one. The data are both collected manually and digitally for subsequent analysis using a relevant method [7].

The collected data are then analyzed using a hermeneutic approach in order to uncover the deepest meanings in the text and is then contextualized with reality outside the text.

\section{Result and Discussion}

The results of this study on the texts of Ibn 'At $\} a>$ Alla $>$ h al-Iskandari as summarized in his book of al-Hikam pertaining to the formation of Muslim identity can be categorized into three identities, i.e. (1) rabbaniya, (2) insaniya, (3) akhlaqiya.

\section{Characteristics of Rabbaniya}

Rabbaniya is an Arabic word in the form of masdar shina'i (noun) rooted from the word "rabb" being added with alif and nun and ended with the particle ya nisbah. The term refers to 
a close intertwine with Allah, which means that a Muslim basically has a personality characterized by a strong and close relationship with Allah in his life, both as Abdullah (the servant of Allah) and khalifatullah (the caliph of Allah) on this earth.

These characteristics are clearly stated in surah Ali Imron verse 79:

$$
\begin{aligned}
& \text { ما كان لبشر أن يؤتيه الله الكتاب والحكم و النبوة ثم يقول للناس كونو ا عبادا لي من دون الله ولكن كونوا } \\
& \text { ربانيين بما كنتم تعلمون الكتاب وبمانها كنتم تدرسون. }
\end{aligned}
$$

"It is not natural for a human being that Allah gave him al-Kitab, wisdom, and prophethood, then he said to humans, 'Let you be my worshipers not worshipers of Allah', But (he said), 'Let you be people rabbani, because you always teach the Quran and because you keep learning it”.

The relationship between a Muslim and Allah enables the former to carry out his or her role as an abdullah (the servant of Allah) because there is a belief that Allah strengthens the heart and shows the proper direction of life. The purpose of life for a Muslim, as described by Ibn 'At $\}$ a $>$ Alla $>$ h al-Iskandari, is:

$$
\text { مطلوب العارفين من الله تعالى الصدق في العبودية و القيام بحقوق الربوبية }
$$

"Thing which is sought by people who knows to Allah Swt is to be able to be right in (carrying out the role) of servitude and can fulfill all the rights (obligations) of the divinity (towards Allah SWT)".

Ibn 'At $\} \mathrm{a}>$ Alla $>$ h al-Iskandari gives fairly clear advice that a Muslim has two purposes: the first is to be a true servant of Allah, namely living in accordance with the Koran and the examples of Rasulullah Saw in his Sunnah. As for the sincerity, Ibn 'At $\} a>$ Alla $>h$ alIskandari gives a clear measure:

$$
\text { إذا أردت أن تعرف قدرك عنده فانظرفيما ذا يقيمك }
$$

"If you want to know your position on Al Mighty Allah side, then look in whether AlMighty Allah established you".

The statement above stressed that the sincerity of a Moslem in establishing a relationship with Allah determines its quality toward Allah. That means the more earnest in maintaining a relationship with Allah, the stronger a Moslem will become the true servant of Allah, but if on the contrary, the life of a Moslem becomes undirected, instead of identity that can be relied upon.

The second goal is to fulfill all obligations as a servant to Allah. This means that a Moslem should prioritize all obligations to Allah. The connection with the first goal is, when a Moslem has become a true servant of Allah, he will inevitably fulfill his obligations towards Allah. In this case, Ibn 'At $\} \mathrm{a}>\mathrm{Alla}>\mathrm{h}$ al-Iskandari states in point of wisdom as follows:

$$
\text { كن بأوصاف ربوبيته متعلقا وبأوصاف عبو ديتك متحققا }
$$


"Make the attributes of the Divinity where you lean on, and realize the characteristics of your servitude with the truth".

The statement confirms that the commitment of a Muslim in fulfilling the obligations imposed by Al Mighty Allah will determine the quality of his or her servitude.

In addition, the close connection between a Muslim and Allah in playing the role of khalifatullah (the caliph of 2Allah) will enable him or she manages the life according to the fitra outlined by Allah. Ibn 'At $\} \mathrm{a}>$ Alla $>\mathrm{h}$ al-Iskandari in one point of his wisdom states:

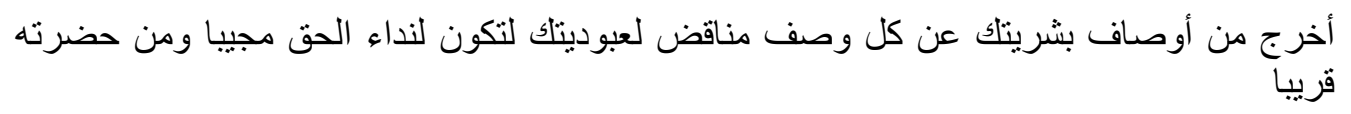

"Get out of your human nature every attribute that is contrary to your servitude so that you can answer the call of Al Mighty Allah and be close to His presence".

Based on this statement, Ibn 'At $\} \mathrm{a}>$ Alla $>\mathrm{h}$ al-Iskandari explained that a Muslim, although granted with human basic values to search for freedom in life, is essentially no more than a servant of Allah alone. These fundamental values can be used as the main capital in order to manage this life so that there is nothing else that appears in this world except the Greatness of Allah in everything.

In the context of the millennial era, it would be a momentum for a Muslim to become more qualified in terms of personality. The achievements in the millennial era should bring a better life and quality for human resources. The characteristic of rabbaniya helps a Muslim become excellent because of the ability to unleash his deepest potential if the transcendent life drives him or her to submission and obedience to Allah alone, as a result of his contemplation and reflection as Abdullah (the servant of Allah).

Similarly, a Muslim should become an intelligent person in taking the role of khalifatullah (the caliph of Allah), in interpreting the existing achievements and in bringing wider benefits for all humanity.

All these roles, of course, will be fulfilled if a Muslim is able to control themself and not to indulge lust in this life because it will be a major barrier to reach Allah, even though it offers the best work for humanity. Related to that, Ibn 'At $\} a>$ Alla $>$ h al-Iskandari provided us with an insightful statement in his wisdom:

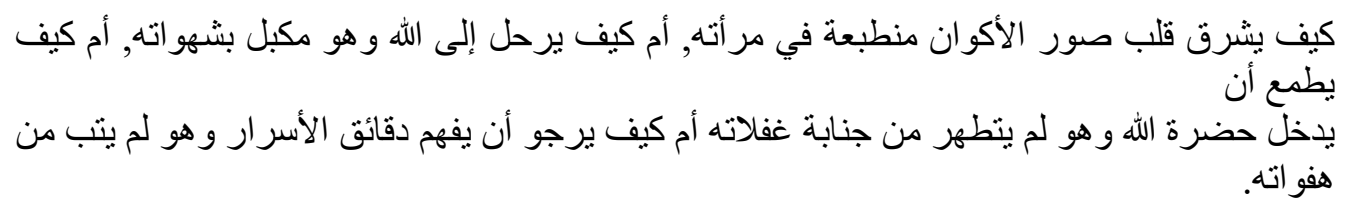

"How it is possible that the heart will emit light while all kinds of creatures are printed, how it is possible to reach Al Mighty Allah, while he is always bound by his lusts, how it will be present toward Al Mighty Allah while he still does not purify himself from neglect, and how he might be able to understand all the secret details while he has not repented of his mistake". 


\section{Characteristics of Insaniya}

Insaniya is an Arabic word, which comes from the basic word insan, being ended with the particle ya nisbah. It refers to one form of characteristic of a Muslim, which is closely related to human values. The connection is based on Islamic teachings that give a priority to human beings. There are at least four aspects that can be observed: (1) human beings have the role of managing life on earth, (2) human beings are created in the best possible form of events, (3) human beings are distinguished from other creatures due to spiritual elements, (4) the universe is submitted for human being. Therefore, the focus of a Muslim in carrying out a role in this life is to uphold the values and principles of humanity.

If the characteristics of rabbaniya mark the quality of close relationship between a Muslim and Allah, then insaniya can be said to be the entrance for a Muslim to present his best work in the name of humanity.

The formula is in accordance with the explanation of Ibn 'At $\} a>$ Alla $>\mathrm{h}$ al-Iskandari in his wisdom:

$$
\text { إدفن وجودك في أرض الخمول فما نبت مما لم يدفن لا يتم نتاجه }
$$

"Plant your existence in the earth of hiddenness, because the growth of something that is not planted is not perfect results".

A Muslim in his life will be associated with the spirit of primordialism, which should be removed as far as possible in order to capture the full portrait of the nobility of human values that should be upheld and then used to carry out the mission on earth on behalf of humanity. The implementation of this characteristic should be under the principle of equality, brotherhood, and freedom.

The manifestation of the principle of equality in Islam is the position of human beings in a respectable and noble status regardless of the background surrounding them. Ibn 'At $\} a$ > Alla $>\mathrm{h}$ al-Iskandari teaches how the principle of equality should be applied:

$$
\text { المؤمن إذا مدح إستحيا من الله أن يثنى عليه بوصف لا يشهذه من نفسه }
$$

"The believer, if he is praised, will feel ashamed of Al Mighty Allah, because he has been praised by an attribute that he has not witnessed in himself".

This gives a lesson that the understanding of the principle of equality departs from the assumption that humanity possesses a virtue or a value of perfection. However, due to primordialism, this virtue will not be able to become a driving force to present the best work that is more varied and distinctive and to gain optimum results.

Then, the second principle is brotherhood. Islam clearly explains that human beings are coming from the same descendant and are bound to the Prophet Adam a.s. Allah explains this in the surah an-Nisa verse 1:

$$
\text { ياأيها الناس اتقو ا ربكم الذي خلقكم من نفس واحدة وخلق منها زوجها وبث منهما رجالا كثير ا ونساء (النساء: 1) }
$$

"O people, fear your Al Mighty God who created you from one soul, then created from him his life partner and spread from there men and women in large numbers. 
This principle means that human beings, especially Muslims, should be responsible for helping each other. Rasulullah Saw said:

$$
\text { عن أنس رضي الله عنه عن النبي صلى الله عليه وسلم قالَ لا يؤمنُ أَحُكم حنَّى يحبَّ لأَخِهِه ما يحبُّ لأخيه. }
$$

"There is no perfect faith in any one of you, so he likes what his brother likes as much as he likes for himself".

While Ibn 'At $\} \mathrm{a}>\mathrm{Alla}>\mathrm{h}$ al-Iskandari advises in his wisdom as follows:

$$
\text { لاتصحب من لا ينهضك حاله و لا يدلك على الله مقاله }
$$

"Do not be friends with people whose spiritual condition does not arouse your spirits, and the words do not lead you to Al Mighty Allah".

The sense of mutual responsibility should be based on the principle of totality. Even the Prophet Muhammad Saw, as it has been mentioned earlier, has given a maximum standard in which one's faith is determined by the totality in offering something to others even beyond his or herself.

Meanwhile, Ibn 'At $\} \mathrm{a}>\mathrm{Alla}>\mathrm{h}$ al-Iskandari provides the context of the intended responsibility. This is related to the potential of a Muslim in taking a role to bring forth enthusiasm in efforts to build a more advanced human civilization by giving something as best as possible, more than what can be achieved and beyond what that can be imagined.

The third principle is freedom. Ibn 'At $\} \mathrm{a}>\mathrm{Alla}>\mathrm{h}$ al-Iskandari mentions in his wisdom:

$$
\text { أنت حر مما أنت عنه أبس ، و عبد لما أنت له طامع }
$$

"You are (human) will be free from what you do not have something for, and you are a servant to what you have something to desire".

The statement can be understood that freedom for human beings means there is no dependence on anything because it makes someone will always be shackled. Meanwhile, a Muslim will become free when he or she has a dependency on Allah since they will be never separated from Allah. Allah Swt actually guarantees the freedom for a Muslim in life.

In the current millennial era, which tends to be dominated by the interests of each individual and where the majority oppresses the minority, a Muslim should come to the front as a person who unites human beings in the name of humanity. Because of its intrinsic nature, human beings have the same role and duty. Likewise, the broken brotherhood should be repaired as it has been mandated by Allah Swt.

\section{Characteristics of Akhlaqiya}

Akhlaqiya is derived from the basic word akhlaq with particle ya nisbah, which means that a Muslim in his life will not be separated from akhlaq values. Indeed, the spirit of Islam is akhlaq, and the essence of akhlaq is tazkiyyat al-nufus, which means purification of the soul.

Finally, Akhlaq has an effective function to strengthen personal relationships between individuals in small nodes in societies. Islam is present in order to connect these nodes to make a strong and mutually reinforcing building into a large civilization. 
Thus, the presence of a Muslim in this life should be significant in building a more advanced civilization based on akhlaq karima as exemplified by Rasulullah Saw. In this case, Ibn 'At $\}$ a $>$ Alla $>$ h al-Iskandari gives a signal in his wisdom:

$$
\text { ما قل عمل برز من قلب زاهد وما كثر عمل برز من قلب راغب }
$$

"No one can be considered a charity that rises from a Zahid heart, nor should it be considered a lot of charity that comes from a heart that loves the world".

It can be understood from the signal above that an effort to build a civilization based on the construction of akhlaq karima is taking the main theme of purification of the soul. It will obviously produce a formidable and durable civilization that brings unlimited utility.

In the context of the current millennial era, global life is no longer a barrier where individuals can interact easily with one another. Therefore, it becomes the right momentum for a Muslim to take a major role in embracing the positive energy in the form of akhlaq karima to build a greater civilization.

\section{Conclusion}

The millennial era that has been taking place now is full of challenges and opportunities for which a Muslim should take a positive role. A Muslim should become a person who is actively taking part in important events in the history of human life. This is because a Muslim has unique and independent characteristics that enable them to manage all the opportunities and challenges in this era.

This characteristic is explicitly mentioned by Ibn 'At $\} a>A l l a>h$ al-Iskandari in his grains of wisdom as summarized in book of al-Hikam, which can be formulated into three characteristics: (1) rabbaniya, (2) insaniya, (3) akhalqiya. These three characteristics can be considered a guarantee for a Muslim to become a person with an independent personality where he or she does not depend on anyone but to Allah.

\section{References}

[1] A. Nata, "Islamic Education in the Millennial Era," Conciencia, vol. 18, no. 1, p. 10, 2018.

[2] Al-Taftazani, Ibn Athaillah al-Sakandari wa tashowwufuhu. Cairo: Maktabah alKahirah al-hadisah.

[3] Al-Rundi, Syarh al-Hikam al-'Athaiyyah li Ibn' Athaillah al-Sakandari. Cairo: Markaz al-Ahram, 1988.

[4] Al-Hanafi, Siraj al-Zalam fi syarh talkhis al-Hikam. Jordan: Dar al-Fath, 2011.

[5] S. Azwar, Research Methods. Yogjakarta: Student library, 2011.

[6] Sarwono.J., Quantitative and qualitative research methods. Yogjakarta: Graha Science Publishers, 2006.

[7] K. S. Ari, “A Practical Approach,” in Research Procedures, Jakarta: Rineka Cipta, 
2013, pp. 274-275. 